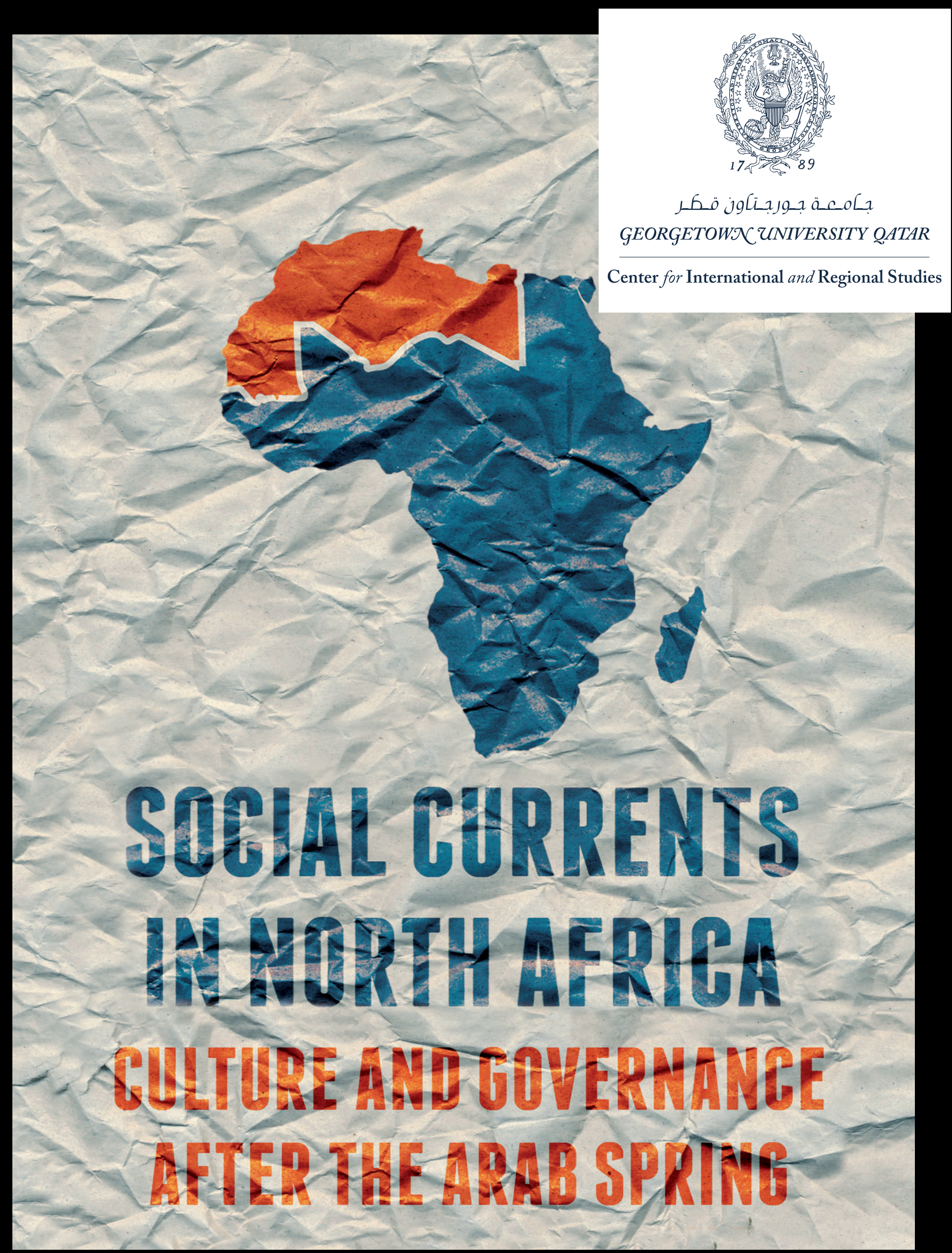




\section{About Georgetown University in Qatar}

Established in 1789, Georgetown University is one of the world's leading academic and research institutions, offering a unique educational experience that prepares the next generation of global citizens to lead and make a difference in the world. Georgetown University in Qatar (GU-Q), founded in 2005, empowers students and shapes the human capacity that the MENA region needs for the 21st century, providing a holistic educational experience built upon the highest academic standards. GU-Q's Bachelor of Science in Foreign Service (BSFS) stresses multidisciplinary studies in a global context. It is the same globally respected program and curriculum offered at the Georgetown University Edmund A. Walsh School of Foreign Service in Washington D.C. The BSFS degree is offered in one of four majors: International Economics, International Politics, Culture and Politics, and International History. Students can also pursue a certificate in one of three concentrations: Arab and Regional Studies, American Studies, or Media and Politics. To learn more about GU-Q's exciting events and programs, or to benefit from its wide array of research, please visit qatar.sfs.georgetown.edu

\section{About the Center for International and Regional Studies (CIRS)}

Established in 2005, the Center for International and Regional Studies at Georgetown University in Qatar is a premier research institute devoted to the academic study of regional and international issues through dialogue and exchange of ideas; research and scholarship; and engagement with national and international scholars, opinion makers, practitioners, and activists.

Guided by the principles of academic excellence, forward vision, and community engagement, the CIRS mission revolves around five principal goals:

- To provide a forum for scholarship and research on international and regional affairs

- To encourage in-depth examination and exchange of ideas

- To foster thoughtful dialogue among students, scholars, and practitioners of international affairs

- To facilitate the free flow of ideas and knowledge through publishing the products of its research, sponsoring conferences and seminars, and holding workshops designed to explore the complexities of the twenty-first century

- To engage in outreach activities with a wide range of local, regional, and international partners.

\section{About the Qatar Foundation for Education, Science and Community Development}

Qatar Foundation for Education, Science and Community Development (QF) is a private, non-profit organization that supports Qatar on its journey from a carbon economy to a knowledge economy. It does this by unlocking human potential for the benefit of not only Qatar, but the world. Founded in 1995 by HH the Father Emir Sheikh Hamad bin Khalifa Al Thani, Emir of Qatar, QF is chaired by Her Highness Sheikha Moza bint Nasser. QF carries out its mission via three strategic pillars: education, science and research, and community development. For more information, visit www.qf.org.qa.

This publication is made possible by the generous support of Qatar Foundation for Education, Science and Community Development. Cover Design: Rob Pinney 


\section{SOCIAL CURRENTS IN NORTH AFRICA}

WORKING GROUP SUMMARY REPORT

(C) 2018 Center for International and Regional Studies

Georgetown University in Qatar

Summary Report No. 23

ISSN 2227-1686 



\title{
SOCIAL CURRENTS IN NORTH AFRICA
}

\author{
WORKING GROUP SUMMARY REPORT
}

CIRS launched the "Social Currents in North Africa" research initiative to investigate variations in social movement mobilization in Tunisia, Libya, Morocco, Mauritania, and Algeria before, during, and after the Arab uprisings. The project examines social and cultural vibrations evident throughout Maghrebi society. The research initiative comprises a series of empirically grounded studies that focus on both comparative and single-country case studies examining social movements and currents in North Africa.

As the first country to depose its leader during the Arab uprisings, Tunisia's political landscape has been in flux since the fall of President Zine El Abidine Ben Ali. The moderate Islamist ruling partyEnnahda-has brought the role of political Islam to the forefront of Tunisia's political debate. In drafting Tunisia's new constitution and addressing its economic crisis, Ennahda has positioned its governance along the Islamist-secular spectrum, bringing it into conflict with social movements-feminists, unionists, and Salafists. Now that Ben Ali's autocratic government has been uprooted, these social groups seek to protect their interests by demanding inclusion and influence in the new political process.

The ousting of Muammer Qaddafi in Libya proved to be less swift and more violent than Tunisia's experience. In the aftermath, tribal mobilization has shaped Libya's social, economic, and political dynamics. Marginalized under Qaddafi's rule through divisive patronage and territorial politics, tribal groups have activated kin-based networks to secure their policy preferences in the post-revolutionary regime. As some of these tribes extend beyond the Libyan borders, their kin-based solidarity plays a vital role in reshaping the balance of power in both regional and national politics.

While the mass protests of Morocco and Mauritania's youth groups-the February 20th and 25th movements, respectively-did not culminate in regime change, they did create avenues for political and social change. In response to the uprisings, King Mohammed VI created a new constitution, raised workers' wages, and made Amazigh (Berber) an official language. The regime conceded to numerous policy demands made by civil society, labor, and ethnic minority groups. For decades, Amazigh (Berber) activists in Morocco, Algeria, and other parts of the Maghreb had been struggling for their rights— particularly in relation to territorial and linguistic autonomy. The recognition of the Amazigh language as an official state language in Morocco's new constitution signals a step in securing rights for this marginalized ethnic group.

Although sporadic protests took place in Algeria, the Arab Spring largely bypassed the country. Social mobilization of Algeria's Amazigh, the Kebyle, has taken place without government concessions. Meanwhile in neighboring Mauritania, another social movement - the Haratin anti-slavery movement - has experienced increased government repression since the Arab uprisings. While slavery is officially outlawed in Mauritania, law enforcement is weak and activists continue to struggle against this practice.

As political change occurs in the region, academic focus on social movement mobilization is both timely and necessary. With its common historical, cultural, socioeconomic foundations, the Maghreb is a cohesive area of study that allows for greater understanding of domestic developments from both a singlecountry and comparative perspective. Moreover, while several books and articles compare various countries of the Maghreb, there is a dearth of scholarship on Mauritania and how it relates to Algeria, Tunisia, Libya and Morocco. This summary report provides synopses of the original chapters published in Social Currents in North Africa: Culture and Governance after the Arab Spring (Oxford University Press/Hurst, 2018). 


\section{SOCIAL CURRENTS IN NORTH AFRICA WORKING GROUP PARTICIPANTS AND CONTRIBUTORS}

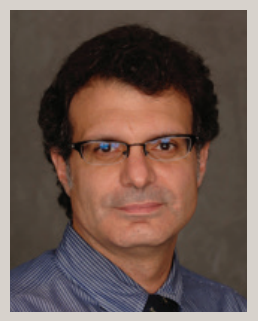

Osama Abi-Mershed

Georgetown University

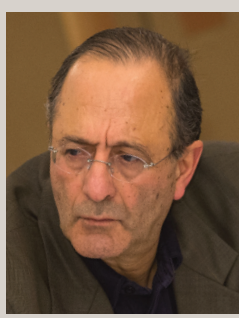

Lahouari Addi

University of Lyon

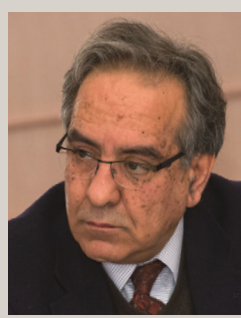

Néjib Ayachi

The Magbreb Center

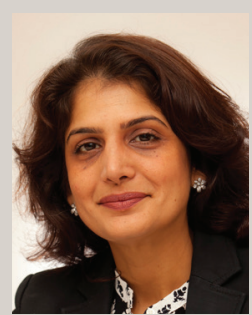

Zahra Babar

CIRS, Georgetown University in Qatar

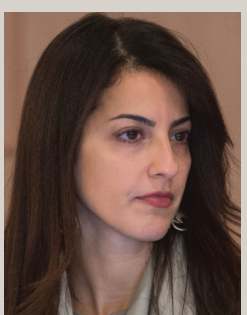

Charis Boutieri

Aomar Boum

University of California, Los Angeles

King's College London

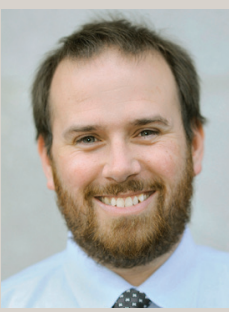

Matt Buehler

University of Tennessee

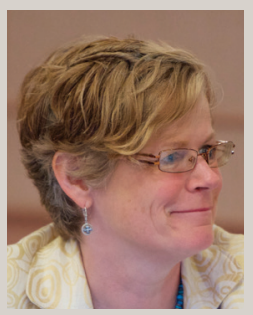

Alice Bullard

Initiative for the Resurgent Abolition Movement - USA 


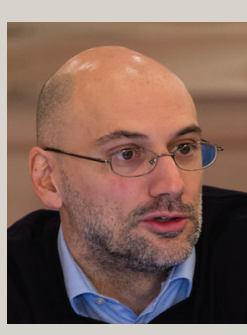

Francesco Cavatorta

Université Laval in Quebec

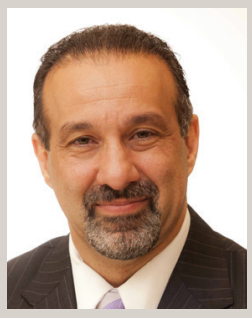

Mehran Kamrava

CIRS, Georgetown University in Qatar

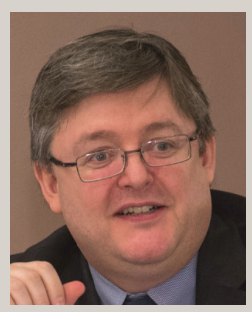

William Lawrence

George Washington University

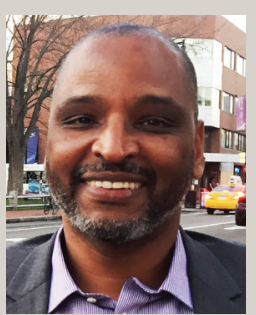

Zekeria Ould Ahmed Salem Northwestern University

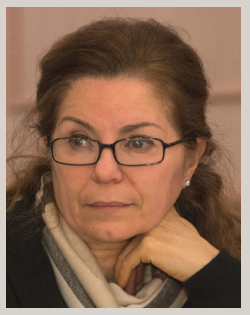

Loubna Skalli-Hanna

American University

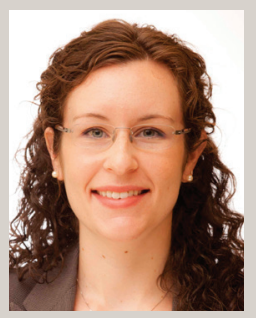

Elizabeth Wanucha

CIRS, Georgetown University in Qatar

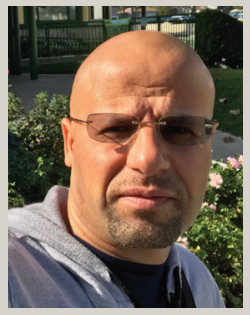

Nouri Gana

University of California,

Los Angeles

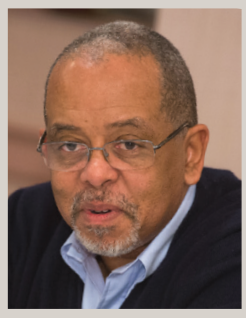

Ricardo René Larémont

Binghamton University, State

University of New York

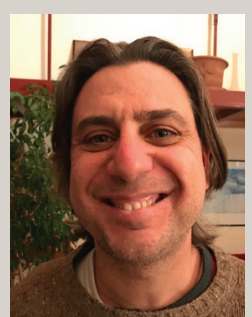

Fabio Merone

Ghent University

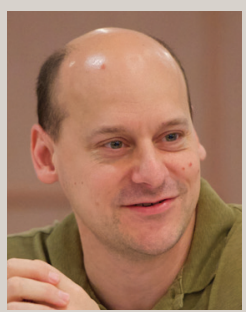

Paul A. Silverstein

Reed College

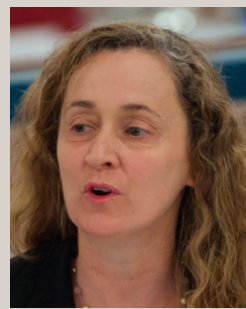

Elizabeth F. Thompson

University of Virginia

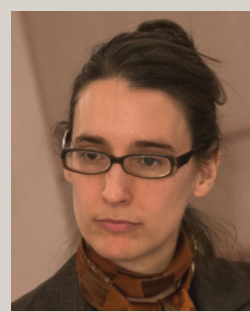

Alice Wilson

University of Sussex 



\section{TABLE OF CONTENTS \\ PAPER SYNOPSES}

1. Social Currents in North Africa

Osama Abi-Mershed, Georgetown University

2. Islamist Parties and Transformation in Tunisia and Morocco

Francesco Cavatorta and Fabio Merone, Université Laval in Quebec, and Ghent University

3. Sufism and Salafism in the Maghreb: Political Implications

Ricardo René Larémont, Binghamton University, State University of Nerw York

4. Labor Protest in Morocco: Strikes, Concessions, and the Arab Spring

Matt Buehler, University of Tennessee

5. The Amazigh Movement in a Changing North Africa

Paul A. Silverstein, Reed College

6. Thou Shalt Not Speak One Language: Self, Skill, and Politics in Post-Arab Spring Morocco

Charis Boutieri, King's College London

7. The Politics of the Haratin Social Movement in Mauritania, 1978-2014

Zekeria Ould Ahmed Salem, Northwestern University

8. Keeping Up with the Times: The Growth of Support from non-State Actors for the

Polisario Liberation Movement

Alice Wilson, University of Sussex

9. $\quad$ Film and Cultural Dissent in Tunisia

Nouri Gana, University of California, Los Angeles

10. "Curating the Mellah:" Cultural Conservation, Jewish Heritage Tourism, and Normalization Debates in Morocco and Tunisia, 1960s-Present

Aomar Boum, University of California, Los Angeles 



\section{Social Currents in North Africa Osama Abi-Mershed}

The contributions to this volume are the outcome of two research workshops on "Social Currents in the Maghreb" organized by the Center for International and Regional Studies (CIRS) at Georgetown University in Qatar in January and June 2014. Scholars in the field of North African or Maghrebi studies were invited to reflect upon their specialized disciplinary or methodological approaches to the region, and comment on the overall validity of North Africa as a cohesive geo-historical unit for social scientific analysis. Such critical reassessments of the disciplinary contours of North African studies have become all the more desirable in light of the momentous and unforeseen sociopolitical upheavals, known as the Arab uprisings, that started in Tunisia in December 2010. The "territory-crossing" reach and substantive implications of the uprisings have compelled North Africanists to review some of the paradigmatic and procedural assumptions in their field of studies, and to don fresh conceptual and methodological lenses when reading Arab societies more broadly. To this end, participants in the CIRS workshops were encouraged to contemplate the following academic questions: Have the Arab uprisings exposed heretofore underestimated regional commonalities for historians and social scientists to explain? Can post-uprising research promote greater analytic rigor and disciplinary synergies in North African studies to the benefit of more varied transregional and comparative perspectives on national developments?

Renowned scholars in the disciplines of political science, history, sociology, anthropology, and media studies-have engaged deeply and critically with the latest social scientific literature on the Maghreb. Separately, their theoretical and empirical approaches to the subject matter aim to situate the distinct structural properties of North African societies, and their individual historical and material specificities, within the broad context of regional and international developments. Taken as a whole, their individual findings confirm that the scientific legibility of North Africa is not fully captured in fixed political divisions and periodizations, or by state-and elite-centered processes alone. Rather, their chapters refine the geohistorical unity of the Maghreb by accounting for social connectivities and flows within the nation-state and across political boundaries. Accordingly, the chapters collected within this volume demonstrate that non-institutional phenomena across time and space-in this case, the congealing of individual ideals and experiences into group practices and social mobilizations-are equally formative to the ongoing project of post-colonial sovereignty, to social construction and deployments of state power, and to local outlooks on social equity, economic prospects, and cultural identity.

Moreover, the workshop participants were called upon to engage with the overarching theme of "social currents," defined here as the manifestation in collective social practices and actions of the experiences and values held in common by members of a given society, and which are essential to their individual identification with larger social groupings. In attempting to historicize the impulses that motivated the Arab uprisings, the organizers of the workshops aimed to shed light on the weight of collective identifications in mobilizing sociopolitical action across North Africa and the Middle East. Social currents were to serve as the prism through which to take meaningful stock of the multiple individual principles, dispositions, and pursuits that merged into the collective and transnational protests of 2010-2011. 
Several chapters underscore the salience of normative beliefs and rules of conduct in maintaining (or challenging) the established sociopolitical order. They consider a range of official and popular projects to redefine the moral contract between North African states and societies, whether undertaken by governments, labor associations, Islamist parties, educational reformers, grassroots activists, or producers of cultural signifiers. Some contributors have situated their understanding of social currents within the formal politico-legal institutions of governance and their sociohistorical effects on systemic political alignments, distributions of wealth, and group affiliations. Others have focused more intently on the ideological mediations by which North Africans are reproduced as subjects of state power: educational systems, mass media communications and representations, cultural and artistic productions, etc. Their combined approaches to social currents in North Africa compel us to reflect more profoundly on the institutional structures and ideological stimuli that have informed recent group behavior and political mobilizations in the Maghreb, and to articulate more theoretical understandings of the social factors that caused the collective needs of North Africans to pressure or outpace the existing regulatory order, establish new social solidarities, and in many cases, trigger a mass social movement.

Osama Abi-Mershed is Associate Professor of History and Director of the Center for Contemporary Arab Studies at Georgetown University. His academic research focuses on the ideologies and practices of colonial modernization in nineteenth-century Algeria, and on processes of state- and nation-making in France and North Africa. His recent publications include the introductory chapter in Perspectives on Western Sahara: Myths, Nationalisms, and Geopolitics (Rowman \& Littlefield, 2014); Apostles of Modernity: Saint-Simonians and the Civilizing Mission in Algeria (Stanford University Press, 2010); and an edited book, Trajectories of Education in the Arab World: Legacies and Challenges (Routledge, 2010). 


\section{Islamist Parties and Transformation in Tunisia and Morocco Francesco Cavatorta and Fabio Merone}

The arrival to power of Islamist parties in Tunisia, Morocco, and Egypt in 2011, following the events of the "Arab Awakening," has led to renewed scholarly interest in Islamist politics. Prior to the Awakening, Islamist parties and movements had nearly faded into insignificance within the scholarship of the Middle East and North Africa, as they seemed to no longer be the most relevant political actors in the region. Two factors contributed to this misperception. First, the thesis of "upgraded Arab authoritarianism" suggested that authoritarian rule in the region would endure unchallenged for the foreseeable future because it had been capable of renewing itself through the 1990s and 2000s. Accordingly, specialists concluded that it was more productive to look at the mechanisms that ensured authoritarian survival rather than to examine long-standing opposition movements. Second, other social actors, namely grassroots movements and liberal groups with a seemingly nonpolitical agenda, were regarded as the new protagonists of Arab civil societies. In addition, Islamism seemed to have moved away from its focus on political power and towards non-political activities. As a result, scholars focused increasingly on either "post-Islamism" or armed Islamist groups, and thus abandoned to a certain extent the study of what could be termed "Orthodox Islamism." The thesis of post-Islamism, which finds its roots in the works of Asef Bayat and Olivier Roy, holds that politically engaged Islamism, having failed to effect macropolitical change by establishing the Islamic state, was progressively disappearing as a political project in favor of more private practices of religiosity. Concurrently, as the "public" engagement of Islamists degenerated throughout the 2000s into acts of violence committed by myriad armed groups operating within and beyond the region, scholars began to pay greater attention to the phenomenon of jihadism.

Thus, with few exceptions among scholars, Islamist parties were gradually neglected as objects of study. This has been particularly true with respect to the Maghreb, where it was deemed that Islamist actors had apparently given up their vision of radical transformation and "disappeared" in the face of modernity, so often touted by authoritarian leaders in the region. In North Africa, Islamism had been contained by co-optation in the political process, by repression, or by self-exclusion. Inevitably then, many policy and academic circles were taken by surprise by the rise of Islamist parties in 2011. Once the general shock subsided, a number of research agendas were developed in order to account for the landslide victory of the Muslim Brotherhood in Egypt, the revival of Ennahda's fortunes in Tunisia, and the impressive results of the Party for Justice and Development (PJD) in the Moroccan legislative elections. At the same time, the thesis of post-Islamism came under severe criticism in the face of concrete evidence that the political project of Islamist parties was not just alive, but was succeeding at the polls.

This chapter surveys the most important debates generated by these research agendas, and argues that, despite some impressive contributions, their focus remains generally limited to certain aspects of Islamist politics. Specifically, post-2011 research agendas continue to dismiss the relevance of party politics due to the longstanding belief-quite justified in most cases-that parties in the Middle East and particularly in North Africa are insignificant political actors. In light of the events of 2011, however, it is necessary to examine party politics more closely, especially the ideologically driven Islamist parties that 
often hold the key to the success or failure of regime change in the region. Scrutinizing Islamist parties can reveal critical social, political, generational, and ideological factors affecting Islamism as a whole, including the Salafi trend. More specifically, scholars must overcome their tendency to overlook the profound diversity, fragmentation, and tensions that exist within Islamism proper, as noted by François Burgat. Such diversity plays a role not only in the political institutional arena (i.e., electoral competition between different Islamist parties), but also in social domains, where there are heated ideological debates and diverse instances and forms of activism within the Islamist sphere that many observers have yet to fully grasp and analyze. Finally, the chapter points to the seeming paradox of the thesis of post-Islamism, which in some ways has been confirmed rather than challenged by the arrival of the Moroccan PJD and the Tunisian Ennahda to power.

Francesco Cavatorta is Associate Professor in the Department of Political Science at Université Laval in Quebec, Canada. He previously served as Senior Lecturer in International Relations and Middle East Politics at the School of Law and Government at Dublin City University in Ireland. His research focuses on democratization and authoritarianism in the Arab world, the role of Islamist parties and movements, and the dynamics of civil society. His recent publications include articles in Middle East Law and Governance, Mediterranean Politics, Democratization, Middle Eastern Studies, and the Journal of Political Ideologies. With Fabio Merone, he edited Salafism after the Arab Awakening: Contending with People's Power (Hurst, 2016). He is co-author of the textbook Politics and Governance in the Middle East (Palgrave, 2015); and co-editor of Civil Society Activism in Syria and Iran (Lynne Rienner, 2013).

Fabio Merone is a post-doctoral fellow at Ghent University. His research focuses on the evolution of Islamism in Tunisian democratic transition. He has been based in Tunisia for over twelve years and is currently working on a project titled, "Tunisia as a secure state: Salafism and post-revolutionary politics in the aftermath of Arab authoritarianism." He has published articles in Democratization, Middle East Policy, the British Journal of Middle Eastern Studies, Middle East Law and Governance and the Journal of Political Ideologies. He is also co-editor of the volume Salafism after the Awakening: Contending with People's Power (Hurst, 2016). 


\section{Sufism and Salafism in the Maghreb: Political Implications Ricardo René Larémont}

During much of the twentieth century, practitioners of Sufism faced extensive critiques from both the jihadist and the anti-colonial Salafi communities, who claimed that Sufi beliefs and practices were heterodox, if not heretical. Even though Sufism had been an indigenous and popular form of religious expression within the region for years, their consistent and heated denunciations of Sufism eventually led to the decline in its practice in the Maghreb. Following this decline, at the end of the twentieth century, political leaders (particularly in Morocco and Algeria) attempted to revive Sufism as a pacifist alternative to jihadi-Salafi beliefs and practices, which they believed encouraged political militancy and threatened the state. This chapter examines societal and state efforts first to discourage Sufism and encourage Salafism during most of the twentieth century, and then to reverse course and try to revive Sufism during the twenty-first century as an attempt to counter the threat of jihadi Salafism.

The practice of Sufism has a long history in the Maghreb, which for the purposes of this chapter include the former al-Andalus (southern Spain). During the Almoravid or Al-Murabitun Empire (1040-1147 CE), al-Andalus was part of the Maghreb and, for the purposes of this discussion, should be included in the analysis. Important practitioners and theorists of Sufism in al-Andalus included, among others, Ibn Bajjah, Ibn Tufail, and Ibn Rushd. We can also include Musa ibn Maimun (or Maimonides) within this mystical tradition because, though Jewish, he practiced mysticism and expressed admiration for the Muslim philosophers and mystics al-Farabi, Ibn Sina, and Ibn Rushd in his famous Guide for the Perplexed. Indeed, his Guide was written in Arabic rather than Hebrew, reflecting the degree to which he had been immersed in Arab culture.

Until the emergence of anti-colonial Salafism and other forms of Salafism in North Africa during the twentieth century, most Muslims in North Africa did not see an inherent contradiction between traditional Islamic belief and Sufi practices. The emergence of the contradiction between traditional faith and Sufism arose only after the propagation of various types of Salafism. Indeed until the emergence of Salafism, Sufi sheikhs rather than members of the 'ulama' had been foremost among North Africa's social and political leaders. They were at the forefront of movements that demanded social justice, which in their view demanded both the creation of an Islamic state and resistance to colonialism. Examples of Sufi resistance leaders in North Africa included the Emir Abdel Qadir, the leader of the Qadiriyya in Algeria, and Muhammad bin Ahmed al-Moqrani of the Rahmaniyya, both of whom resisted French colonialism in Algeria; Muhammad bin Ali al-Sanusi who led the charge against Italian colonialism in Libya; Muhammad Bu Dali, the leader of the Darqawiyya order in Algeria, who led a revolt against Ottoman rulers; and Muhammad al-Sharardi who challenged the authority of the sultan in nineteenth-century Morocco. In West Africa, Uthman dan Fodio created an Islamic state in what is now northern Nigeria, and Al-Hajj Umar Tall led a revolt to do the same in Futa Jallon and Futa Toro (in contemporary Guinea and Senegal). All these resistance leaders were Sufis.

While there are many Sufi orders in North Africa, this chapter focuses on the larger and more influential orders, including the Shadhiliyya, the Shadhiliyya-Jazuliyya, the Shadhiliyya-Darqawiyya, the Qadiriyya, the Tijaniyya, the Sanusiyya, and the Qadiriyya-Boutchichiyya orders. 
Ricardo René Larémont is professor of political science and sociology at SUNY Binghamton and an Atlantic Council Senior Scholar. His principal books include: Al-tasawuf al-maghrebi: qadaya muasira (Moroccan Cultural Studies Centre, 2017) with Khalid Bekkaoui; Pursuing Security and Shared Development in Euro-Mediterranean Migrations (Aracne, 2017) with Emanuela Claudia del Re; Revolution, Revolt, and Reform in North Africa (Routledge, 2013); Al-rabia al-arabi: al-intifada w'al islab w'al-thawra (Al-Maaref, 2013) with Youssef Sawani; Islamic Law and Politics in Northern Nigeria (Africa World Press, 2011); Borders, Nationalism, and the African State (Lynne Rienner, 2005); The Causes of War and the Consequences of Peacekeeping in Africa (Heinemann, 2002); and Islam and the Politics of Resistance in Algeria, 17831992 (Africa World Press, 2000). His research has been supported by the Carnegie Corporation, the Ford Foundation, the Rockefeller Foundation, the United States Institute of Peace, the Office of Naval Research, and the United States Department of Education. 


\section{Labor Protest in Morocco: Strikes, Concessions, and the Arab Spring Matt Buehler}

A growing body of evidence suggests that organized labor associations-members, activists, and leaders of unions-played an important, contributing role to many of the popular protests that swept the Arab world beginning in late 2010. Although neither the originators nor instigators of these protests, labor syndicates contributed to demonstrations and enhanced their size and strength. In Tunisia, seasoned unionists of the Union Générale Tunisienne du Travail (UGTT) participated in protests in Sidi Bouzid, Gafsa, and other small towns in the country's interior before demonstrations migrated to Tunis. In Egypt, mobilization of unions occurred before the Arab uprisings, beginning in 2006, especially among textile workers in the city of al-Mahallah al-Kubra. Their strikes and protests continued during the unrest of 2011. While scholars are beginning to produce research that focuses on labor protest in Tunisia and Egypt during the Arab uprisings, little has been published with an empirical focus on Morocco. To this end, this chapter analyzes the nature of labor protest in Morocco in 2010-2011, and relays the sequencing of events that sparked union unrest in the country. It also describes what (if any) labor demands were realized through participation in protests, and seeks to answer the following question: What role did unions play in the mass mobilizations organized by Morocco's youth movement, the 20 February Movement for Change?

To answer this question, this chapter explores the theory of labor aristocracy in the context of statelabor relations in Morocco. First conceived by Marx, and further developed by Hobsbawm, the theory of labor aristocracy posits that workers are not uniform in their assertiveness toward employers, but rather vary in how they press for material demands. The labor aristocracy is comprised of workers with specialized skills who understand their value to industrial production and firm profits. Were these skilled laborers to strike, their stoppage would seriously diminish the profits of owners. Longshoremen, for example, are a classic example of such labor aristocrats. Their strikes reduce profits by disrupting import-export trade, which causes delays in shipping and spoilage of goods. Because employers understand the economic value of these skilled laborers, the latter can use both strikes and threats to strike to elicit concessions from the former. By threatening to strike and walk out of wage negotiations, skilled laborers can draw greater benefits from their employers than if they had undertaken these contentious actions directly, without first bargaining in face-to-face talks.

This chapter is divided into four sections that outline the origins of Morocco's labor unions and detail their involvement in the country's uprisings of 2011. First, the chapter surveys the historical foundations of labor unions in Morocco, focusing on the colonial and post-colonial periods. This early history demonstrates that Morocco's unions have a history of inciting violence to advance their agenda, especially in urban areas, which have historically served as centers of opposition to the monarchy. Second, it sets the baseline to show that, like in Tunisia and Egypt, the period preceding the Arab Spring was marked by increased labor unrest in Morocco. Third, it examines union mobilization during the height of popular protests against Morocco's regime, from February to June 2011. Finally, the chapter closes by discussing what demands the unions secured from their activism and reviews the key implications from the political historical narrative. The empirical record bears out the argument that labor unions used unrest connected to Morocco's "Arab Spring" to realize some of their core material demands. 
Matt Buehler is a 2017 fellow at Harvard University's Middle East Initiative at the Belfer Center for Science and International Affairs within the John F. Kennedy School of Government. He is an assistant professor of political science at the University of Tennessee, and is also a global security fellow at the Howard H. Baker Center for Public Policy. Previously, he was a post-doctoral fellow at the Center for International and Regional Studies, Georgetown University in Qatar. His research area is comparative politics with expertise in the Middle East, and his interests include democratization, authoritarianism, the Arab uprisings, public opinion research, Islamist movements, and North African politics. His book, Why Alliances Fail: Opposition Coalitions between Islamists and Leftists in North Africa, is under review with Syracuse University Press. Other publications include: "The Autocrat's Advisors: Opening the Black Box or Ruling Coalitions in Tunisia's Authoritarian Regime" (2017); and "Do You Have 'Connections' at the Courthouse? An Original Survey on Informal Influence and Judicial Rulings in Morocco" (2016), both published in Political Research Quarterly. 


\section{The Amazigh Movement in a Changing North Africa Paul A. Silverstein}

This chapter draws on the decades-long struggle for Berber/Amazigh rights to argue that the recent revolts follow a long fight for cultural and political inclusion that has been animated by a variety of challengers to authoritarian rule-themselves coming from a range of political persuasions, religious pieties, and ethnic identifications. Indeed, over thirty years before the Arab Spring, activists and scholars had already recognized a "Berber Spring" that had left behind an important legacy of political activism for North African citizens, particularly for those living in the Berber-speaking peripheries. If the recent uprisings called world attention to the plight and agency of small communities of Berber speakers in Tunisia and Libya, much larger swathes of self-identified Berbers (or "Imazighen") in Algeria and Moroccoaided by diasporic Berbers in Europe and North America-have been for decades outspoken in their demands for cultural and linguistic recognition and in their decrying of institutionalized socioeconomic marginalization. Indeed, since the late 1960s, Berber language and culture have become the object of sustained reflection, objectification, resistance, and co-optation in a high-stakes political game over the future of post-colonial North African nation-states heretofore unified under the mantle of Islam and Arabic language. Until the mid-1990s, Amazigh activists, often young men aligned with Marxist oppositional movements, were subject to arrest, detention, imprisonment, and violence for public displays of Berber language (Tamazight) and calls for its national recognition. More recently, the Algerian and Moroccan governments have co-opted Amazigh activists in their struggles against the Islamist opposition and have moved to incorporate Tamazight into the education and media systems as a public gesture of political openness and cultural tolerance, but they continue to suppress ongoing efforts by activists to forge economic and political autonomy in Berber-speaking communities.

This chapter traces transformations in Amazigh militancy over the past fifty years. Its engagements have gradually shifted from particular demands for cultural and linguistic recognition toward a broader advocacy for social justice, political transparency, and economic equity that parallel those of student, labor, feminist, and human rights movements. These are demands that congealed in the 2011 mass demonstrations across North Africa and that explicitly sought to transcend extant ethnic and religious divisions within the region. Alongside these other groups, Amazigh activists lent organizational experience and know-how, a facility with social media, and a cult of martyrdom, which marked not only the Moroccan 20 February Movement but also the revolts in Libya and Tunisia in which Berber citizens were notably involved. Their long-term insistence on decentralization and diversity within the nation-state mapped out an alternative to top-down state-society relations and a model for post-authoritarian governance structures, while such horizontalism ultimately demonstrated similar tendencies to internal fragmentation and state co-optation in the uprisings, as it had throughout the history of the Amazigh movement. Today, the Amazigh movement's imagination of a broader cultural-geographic space of Tamazgha (Barbary) stretching from the Canary Islands to the Egyptian Siwa oasis continues to provide an alternate model for thinking beyond the narrow national interests that had sunk previous, official efforts to enact North African unity. Even as Amazigh activists remain fractured along generational, class, and indeed regional/national lines, their efforts at 
organizing through “world” federations, supranational bodies (e.g. the United Nations), diasporic resources, and delocalized social media point to alternative vectors for rethinking North Africa beyond a set of discrete nation-states. The Amazigh movement thus provides a salient lens for examining contemporary social currents in North Africa.

Paul A. Silverstein is Professor of Anthropology at Reed College. He is the author of Algeria in France and co-editor of Memory and Violence in the Middle East and North Africa (Indiana University Press, 2004, 2006). His recent research on Amazigh activism, racial politics, migration, and territorial development in southeastern Morocco has appeared in The Journal of North African Studies, Material Religion, Nations and Nationalism, The Brown Journal of World Affairs, and the Middle East Report, as well as in a number of edited volumes. He is co-editor of the book series "Public Cultures of the Middle East and North Africa" with Indiana University Press, and chair of the board of directors of the Middle East Research and Information Project (MERIP). 


\section{Thou Shalt Not Speak One Language: Self, Skill, and Politics in Post-Arab Spring Morocco Charis Boutieri}

The widespread movement of contestation that swept through urban Morocco during the Arab Spring (2011-2012), known as Harakat 'ishrīn fibräir (20 February Movement), made därija (Moroccan Arabic) central to its articulation of disaffection with economic hierarchies, existing institutional structures, and modes of sociocultural engineering. The majority of its street slogans and online campaigns, which were featured on sympathetic websites such as Mamfakinch [We will not give in] and Lakome [To you], posited darija as the voice of the "people" addressing "authority." Authority was associated, on the one hand, with royal and governmental edicts in fușha (Classical Arabic) and, on the other, with elite symbolic and material capital most often contingent on francophonie. The widespread demands for shughl (work), karāma (dignity), and 'adāla ijtimá' 'iyya (social justice) need to be seen in relation to the linguistic registers in which they were enunciated, not least because the Moroccan state did exactly that.

The new constitution, drafted by a consultative commission of eighteen members that King Mohammed VI appointed himself and ratified via referendum on July 1, 2011, took a considerably revised position towards Morocco's languages. Specifically, article five reinstated fushā as the official language of the country but added the amazighiyya (Amazigh/ Berber) as the second official language and proclaimed that it was to be promoted in public education and the wider public sphere. The article then proceeded to guarantee the state's preservation of hassaniyya (Hassani) — the Arabic Bedouin register spoken in the south of Morocco and Algeria, the contested Western Sahara territories, and the Sahel-as an integral component of al-hawiyya al-thaqäfyya al-maghribiyya al-muwāhhada (the unified Moroccan cultural identity). Without mentioning specific foreign languages, article five strongly encouraged their mastery with a view to intensify interaction with and integration into the global mujtama' al-ma'rifa (knowledge society). The constitutional article presented Morocco's "Arab and Berber" languages in the plural as constituents of a singular, authentic patrimony and as resources for the future.

To an extent, this performance of recognition sanctioned what is already happening in private and public social interaction and in print, visual, and social media: an ever expanding and all the more visible multilingualism among Morocco's spoken Arab and Berber registers, between versions of Arabic, and between Arabic and foreign languages, mainly French and English. The weight of this constitutional performance lay in its marked shift from earlier official rhetoric around the languages and cultures of Morocco and, through this move, its signaling of the emergence of a new nation-state attuned to the role of diversity as an index of liberal democratization. Yet a celebration of this particular institutionalization of multilingualism should be cognizant of a number of caveats. First, the singularity of culture and patrimony pronounced in article five elides conspicuous fissures across class, regional, and gender lines that greatly impact the way differently positioned citizens apprehend "Moroccan-ness." Second, this linguistic configuration does not at all reflect the political economy of the country, which reserves little space for fuṣhā speakers and even less for monolingual Amazighophone or hassaniyya speakers. In fact, this political economy traditionally depended on francophonie and is gradually leaning on the anglophonie. Third, this narrative of national reinvention is situated amidst international appeals from Morocco's economic patrons 
for legislatively safeguarded pluralism. In turn, such appeals for pluralism dovetail with the neoliberal enterprise on a global scale by foregrounding language and culture as objects of commodification within a presumably open arena of competition. Given the above, this chapter aims to probe the relationship between multilingualism and diversity with two aims: first, to examine the social impact of Moroccan multilingualism within the frame of global market capitalism, and, second, to use social experience to unsettle the assumed tautology between institutionalized diversity and liberal democratization.

Charis Boutieri is Assistant Professor in the Social Anthropology of the Middle East at King's College London. Her research addresses knowledge production and dissemination in North Africa (Morocco and Tunisia), the imbrication of colonial, nationalist, and international development agendas in the structure and experience of education, language and power, lived democracy and democratization, and youth. Her recent publications include Learning in Morocco: Language Politics and the Abandoned Educational Dream (Indiana University Press, 2016); a contribution in Wired Citizenship: Youth Learning and Activism in the Middle East (Routledge, 2014); and articles in the Anthropology and Education Quarterly (2013) and the International Journal for Middle East Studies (2012). She has also written opinion pieces for the online publications Jadaliyya and Open Democracy and is cofounder of the Maghreb Academic Network, the first academic forum focused on the Maghreb region in the UK. 


\section{The Politics of the Haratin Social Movement in Mauritania, 1978-2014 Zekeria Ould Ahmed Salem}

The Islamic Republic of Mauritania is often referred to as "slavery's last stronghold." Mauritania has earned this unenviable title due to the existence of descent-based domestic slavery in the country despite successive abolition decrees put in place since the 1960s. Advocating for the eradication of slavery and its vestiges, El-Hor (meaning "free man" or "freed man" in Arabic) is a social organization that has been present on Mauritania's political scene for almost four decades. Launched as an underground movement in March 1978 by a handful of young activists, El-Hor presented itself as an organization for the liberation and emancipation of the Haratin, a group in Mauritanian society made up of slaves, former slaves, and their descendants. Having ties to Black African ethnic groups, with whom they share their ethno-racial origin, and the Arab-Berber group, with whom they share their language and culture (Moorish and Arabic), the Haratin are important players in the demographic and cultural equation at the heart of Mauritanian national identity. This social movement-led exclusively by victims of slavery and their descendants within a social and political environment where the social condition of the Haratin community was emerging as a critical issue-projected a pioneering character. Even though the forms of resistance enacted by the Haratin have begun to attract the attention of some scholars, the many changes brought about through the movement have not been thoroughly examined. The purpose of this chapter is to help fill this gap in the body of research. This is especially important for influencing scholarship in Mauritania's wider region, where racial and ethnic issues are often overlooked by analysts of social currents.

This chapter draws on qualitative data collected in the field over approximately ten years, in order to understand how the Haratin have sought equality and justice primarily through fighting the stigmas attached to slavery (and the relics of slavery), and by challenging the political marginalization that has secured their subordination. The analysis explores the context in which the Haratin movement began, the evolution of the rhetoric it has used to articulate dissent, its politics, and the growing diversity of the organizations that have devoted themselves to the Haratin cause. The ways in which the generational divide among activists has shaped the movement's actions without changing its core demands are outlined in this chapter. In the second part of the chapter, attention is devoted to analyzing the patterns of conflict and cooperation over time, not only within the movement, but also in its rather ambiguous relationships with other social and political actors.

This chapter explains how the complex intersectionality of ethnic and cultural identities has made it difficult at times for non-Haratin communities to accept the legitimacy of the Haratin cause. This has led social movements defending the Haratin cause to take unexpected forms, especially in the context of the "political liberalization parenthesis" that has opened from time to time in the country since the early 1990s in the wake of the so-called "third wave of democratization" in Northwest Africa. It is then argued that not only has the Haratin movement been an important player in Mauritania's various attempts at democratization, but also that, despite its shortcomings and setbacks, the so-called "political liberalization" process in the country has allowed the Haratin movement the opportunity to advance its social and 
political agendas. This advancement is illustrated through the political careers of the two major figures of the Haratin movement: Messaould Ould Boulkheir, the father figure of the E1-Hor movement, and Birame Ould Dah Abeid, the aspiring and outspoken radical leader of the Haratin social movement who has recently attracted international media coverage. The trajectory of these two leaders exemplifies the historic changes that affected the movement, as well as the general trend traced in this chapter.

Zekeria Ould Ahmed Salem is Associate Professor and Director of The Institute for the Study of Islamic Thought in Africa (ISITA) at Northwestern University. Previously, he was Professor of Political Science at the University of Nouakchott in Mauritania. He was a visiting Fulbright Scholar at the University of Florida from 2010-2011, and served subsequently as a Senior Visiting Fellow at the Institute for Advanced Study in Paris (2012) and Nantes (2013). His most recent book is titled Prêcher dans le Désert: Islam politique et changement social en Mauritanie (Karthala, 2013). Other publications include a casestudy chapter on Mauritania in Islamist Radicalization in North Africa: Politics and Process (Routledge, 2011); a chapter on the transformations in the Haratin movement in Mauritania in Movers and Shakers: Social Movements in Africa (Brill, 2009); and a chapter in Islam and Muslim Politics in Africa (Palgrave Macmillan, 2007). He has also published articles in the Canadian Journal of African Studies (2010) and The Journal of North African Studies (2005). 


\section{Keeping Up with the Times: The Growth of Support from Non-State Actors for the Polisario Liberation Movement}

\section{Alice Wilson}

The era of decolonization in the 1960s and 1970s saw the founding of a number of armed movements, often in post-colonial contexts, seeking to capture state power. In the context of the Cold War, the support of state actors for these movements was, in many cases, of crucial importance. Nevertheless, following the collapse of the Soviet Union, some scholars have argued that, if the support of states continues to be important, the support of non-state actors has become increasingly significant for armed movements that seek to capture state power. The conflict in Syria that developed out of the 2011 uprisings certainly seems to illustrate this trend. Alongside support from outside state actors such as Russia, there have also been private donations from wealthy individuals, especially in the Gulf, who have equipped brigades and contributed to the proliferation of armed rival groups.

If a post-Cold War trend is for armed movements to draw on the support of both state and non-state actors, how might a movement that began in the Cold War era- and has continued to benefit from the strong support of a state ally-nevertheless have adapted over time? In this chapter, I examine this question for the longstanding armed liberation movement for Western Sahara. From its early days, the Polisario Front (henceforth Polisario) appeared to be a typical anti-colonial liberation movement. Since shortly after its foundation, Polisario has benefitted from significant support from neighboring Algeria. Crucially, this support includes the provision of safe haven in Algeria, along with diplomatic and material support.

Over its four decades of existence, however, Polisario itself, the international context in which it operates, and the situation of the people whom it claims to represent, have inevitably changed. Many dimensions of these transformations, both in Polisario's environment and in its own policies, have been studied, such as Polisario's shift to explicit acceptance of a market economy, its attempts to democratize, and its attempted embrace of a human rights agenda. Taking these shifts as a springboard, in this chapter, I focus my analysis on the political impact of the changing importance of the support of state and nonstate actors for Polisario, an area that has not yet been fully explored. I argue that for Polisario, as for other armed movements in the 1990s and 2000s, the support of non-state actors has become increasingly important. In Polisario's case, these non-state actors include the growing Sahrawi diaspora, especially the diaspora in Spain, but also new nongovernment organizations (NGOs) and multilateral organizations' forms of support, such as sponsorship for infrastructure or government personnel in the Sahrawi refugee camps. To clarify, I do not wish to overlook the importance of support for Polisario from non-state actors in the Cold War period. Indeed, as I shall discuss, Polisario benefitted in its early years from the support of European activists and NGOs. Rather, I seek to show how in the post-Cold War period the support of non-state actors has both proliferated and increased in importance in the sense that it has allowed Polisario to undertake new kinds of activities above and beyond those it could undertake with only the support of state actors such as Algeria.

The growth of non-state forms of support for Polisario has had implications beyond the scope of traditional state support. First, the rise of these new forms of support suggests that Polisario is an "upto-date" armed movement, in the sense that its transformations include having developed a growing 
range of non-state allies. Second, these new forms of support mean that the oft-foregrounded description that Polisario is an Algerian-backed movement needs to be supplemented in order to take into account the increasing significance of non-state actors' support for Polisario. Third, the rise in the importance of support from non-state actors foregrounds an interesting tension, or flexibility, for Polisario. Whilst the states that have supported Polisario, including Algeria, have supported it as an armed movement, the support of non-state actors is more ambiguous. Some non-state actors in the Sahrawi diaspora are vocal in explicitly supporting Polisario as an armed movement, and demand a return to war. Nevertheless, the activities of NGOs and multilateral organizations focus on civilian initiatives. This suggests a potential future tension that Polisario might not, in the long term, be able to satisfy both kinds of supporters. In the meantime, however, although Polisario has not disarmed, the support it receives for civilian initiatives has allowed it to pursue activities comparable to those of unarmed social movements in the region (e.g. cultural activities, art festivals, and an annual cinema festival). The support of non-state actors has become a significant resource that allows Polisario to blur the boundaries of being an armed vs. an unarmed movement. While this very ambiguity may raise questions about Polisario's future retention of different supporters, for now it seems to be a contributing factor to Polisario's resilience as a movement that seeks state power.

Alice Wilson is Lecturer in Social Anthropology at the University of Sussex, UK. Her research interests include state power, sovereignty, citizenship, taxation, and forced migration, with a geographical focus on the Middle East and North Africa. Her book Sovereignty in Exile: A Saharan Liberation Movement Governs (University of Pennsylvania Press, 2016) examines revolutionary state power in the government-in-exile led by the liberation movement from Western Sahara. Sovereignty in Exile won Honorable Mention in the 2017 book prize for the Middle East Section of the American Anthropological Association. Wilson is co-editor of the special issue "Understanding Legitimacy: Perspectives from Anomalous Geopolitical Spaces" in Geoforum. 


\section{Film and Cultural Dissent in Tunisia Nouri Gana}

In post-revolutionary Tunisia, there is hardly a public debate over any pressing political, economic, or social issue-ranging from national security, tourism and labor strikes, to accountable governance and institutional reform - that does not ultimately devolve into a "blamestorming" exercise. Participants apportion blame for the deterioration of the state of affairs (taraddi al-'awd $\bar{a}^{\prime}$ ) to figures of the ancien régime of Ben Ali or discredit or champion others, establishing their own revolutionary credentials in the process. This obsessive return to the pre-revolutionary situation in an all-out war of positions, which has become a constant feature of political debate after the revolution, has cast its long shadow on the cultural scene, in which everything came to be valued, attacked, or embraced depending on its perceived affinity with the revolution or the counterrevolution led by the remnants of the old regime.

The value of artists and public intellectuals has come to be routinely reassessed in post-revolutionary Tunisia in relation to the nature and degree of their past association (if any) with Ben Ali's regime, a process that was made easier after bloggers and cyberactivists published several lists of artists and public figures who allegedly supported Ben Ali in his 2014 re-election bid. These lists included the names of iconic filmmakers Moufida Tlatli and Abdellatif Ben Ammar, actress Hind Sabri and actor Hichem Rostom, as well as several famous singers, such as Latifa al-Arfaoui, Nabiha Karaouli, Amina Fakhit, Sonia M'barek, and Saber Reba'i, in addition to Lutfi Bouchnaq. Some of these local celebrities might not have chosen to be on the list of signatories, but may have been named by Ben Ali's entourage and included on the list without their consent. Even though they may not be held in public opinion as guilty of explicit involvement with Ben Ali's regime, they are still subject to the tacit implication that they have been complicit in the regime's search for longevity.

While many artists, especially popular singers, who thrived under the Ben Ali regime experienced a rude awakening, or a fall from grace of sorts, after the events of December 17, 2010 and January 14, 2011, others, who had previously opposed Ben Ali, and were consequently forced to disappear from public view, were catapulted to instantaneous, albeit long overdue, fame. Many of those whose reputations declined in the wake of January 2011 due to perceived connections to the regime, have attempted to hitch their wagons to the train of revolution and have managed to redeem themselves, at least partially. Those who enjoyed overnight fame, or belated acknowledgment of their revolutionary credentials, found themselves suddenly caught in the polarizing political atmosphere of post-revolutionary Tunisia.

With the post-revolutionary overdose of political debates raging in public and virtual spaces, the unprecedented proliferation of political parties, the relentless wars of positions and the adhocracies of political alliances, the current Tunisian cultural sphere risks becoming further captive to political events. The countrywide unity that brought together thousands of Tunisians in mass demonstrations against Ben Ali's regime has now largely given way to disunity and divisiveness along ideological lines and party politics. Artists and intellectuals whose varying positions in the debates (and/or how the public viewed those positions) eventually voided the deep commonalities their pre-revolutionary struggles against Ben Ali's regime had shared. However, rediscovering these pre-revolutionary commonalities of struggle is 
more important than ever as some have argued that cultural debates and controversies have hindered the transition to democracy, eclipsing in the process the significant role culture previously played in the making of the Tunisian revolution.

The purpose of this chapter is to address the value of cultural politics in the gradual emergence of a dissident social imaginary. Perhaps because of the rigidity of censorship and the severity of self-censorship during the successive dictatorships of Bourguiba and Ben Ali, one of the remarkable constants of Tunisian cultural products is that much of what would count for political dissidence has been couched as forms of social or cognitive dissonance, in which the norms of social intelligibility collapse and with them all sorts of taboos. Nowhere else is this as evident as in postcolonial Tunisian films produced in the last three decades. This chapter seeks to disentangle the common genealogies of cultural resistance and dissidence that have characterized the artistic ventures of a number of filmmakers in postcolonial Tunisia. These shared genealogies seem to have been forgotten amidst the vociferous political debates that have come to characterize post-revolutionary Tunisia. This chapter excludes other forms of cultural expression (such as theater, music, and literature) in order to focus on film.

Tunisian film is undoubtedly part of the tradition of creative and discursive dissidence. It may not always be possible to measure the extent to which modern Tunisian cinema stirred political contention in public life, much less to gauge the role it played in the popular mass uprising of December 2010. But this is not necessarily undesirable. To establish causality between cinematic dissidence and social insurrection and revolt is precisely to reduce filmic representation to ideological premeditation. The goal of cultural politics is not necessarily immediate policy or regime change, but rather the transformation of public life through the generation of a new social imaginary, a new mode of organizing social relations that is different from the status quo. These new social imaginaries are not created by individual films, but through the concatenation of multiple films, and other cultural products, over time. While a film may not result in regime change, I argue that a new social imaginary will make such a change possible.

Nouri Gana is Associate Professor of Comparative Literature and Near Eastern Languages and Cultures at the University of California, Los Angeles. He has published articles and chapters on the literatures and cultures of the Arab world and its diasporas in such scholarly venues as Comparative Literature Studies, PMLA, Public Culture, and Social Text. He also contributed op-eds to The Guardian, El Pais, Electronic Intifada, Jadaliyya, and CounterPunch. He is author of Signifying Loss: Toward a Poetics of Narrative Mourning (Bucknell University Press, 2011), and editor of The Making of the Tunisian Revolution: Contexts, Architects, Prospects and of The Edinburgh Companion to the Arab Novel in English (Edinburgh University Press, 2013). He is currently completing a book manuscript on the politics of melancholia in the Arab world and another on the history of cultural dissent in colonial and postcolonial Tunisia. 


\section{0. “Curating the Mellah:” Cultural Conservation, Jewish Heritage Tourism, and Normalization Debates in Morocco and Tunisia, 1960s-Present}

Aomar Boum

In the midst of the Arab, Islamic, and international calls for boycott, divestment, and sanctions against Israel, a handful of Arab countries-Lebanon, Morocco, and Tunisia-have engaged in a number of projects to restore local Jewish sites and synagogues. In Lebanon, the Magen Avraham synagogue, which recently opened its doors for religious services, has been restored largely through donations from Lebanese Jews in the diaspora. However, Tunisia and Morocco remain the most celebrated countries in which the revival of Jewish heritage is not only part of the political discourse of the government, but also a key aspect of the tourism industry. While President Habib Bourguiba and King Hassan II played a major role in nurturing direct political engagement with Israel dating back to the early Arab-Israeli wars in the 1960s and 1970s, the celebration of Jewish heritage and its conservation emerged as a social trend within the Jewish diaspora as a way to rediscover Tunisian and Moroccan heritage, gaining momentum after the Oslo agreement. The rediscovery of Jewish heritage — and its underlying economic benefits- has produced varied internal social and political reactions in Tunisia and Morocco since their independence in 1956.

In this chapter, I explain the context for this political and cultural current of rediscovering and conserving Jewish heritage, and I highlight the internal political dynamics and challenges it faces today. I discuss the movement of cultural renovation and marketing of Jewish heritage in Tunisia and Morocco and its ties to the development of a Jewish cultural tourism that targets Israeli tourists of North African descent (and sometimes those of Ashkenazi descent as well). Equally important, I analyze the political and social debates about Israeli relations with Morocco and Tunisia, and Jewish-Muslim relations that have been generated by this movement of cultural preservation. Unlike Algeria, which has mostly dismissed these forms of cultural dialogue, Tunisia and Morocco have largely embraced them because of the positive connections its Jewish communities have with both countries. I argue that this movement has a philo-Semitic dimension given its focus on Jewish capital and tourism revenues rather than on a serious national debate about the place of Jews as citizens in Morocco and Tunisia. While Jews are admired as successful business owners and traders, they are socially and religiously stigmatized because of their direct or indirect links to the conflict between Israel and Palestine. Therefore, negative perceptions of Jews are seen largely through debates revolving around the appropriateness of normalizing relations with Israel, especially after the Arab uprisings. I also contend that despite the relative physical absence of Jews in Tunisia and Morocco today, they still play a role in the political economies of both countries to the extent that important sections of the tourism industries cater to Jews who trace their descent to both countries. Therefore, even with the damaging political impact of the Arab-Israeli conflict on perceptions of Jews in Morocco and Tunisia, governments are still using their countries' historical Jewish heritage to market a living Jewish culture in North African cities and villages.

On May 2, 2013, the Washington-based Cape Verde Jewish Heritage Project (CVJHP) organized a ceremony to honor a small-and close to extinct-Jewish community on the Island of Santiago in the town of Praia, the capital and largest city of Cape Verde. During the nineteenth century, many Jews from northern Morocco resettled in Praia in search of trading and commercial opportunities. With only a few 
Jews left in Cape Verde today, the cemetery and Jewish heritage of the community declined into oblivion. Yet, the historical connections of Cape Verde's Jewry to Morocco led the CVJHP to seek donations from King Mohammed VI, who contributed a sum of $\$ 100,000$ to renovate the Jewish tombs.

The connections between safeguarding Jewish quarters and neighborhoods, heritage tourism, interfaith dialogue, tolerance, and normalization of relations with Israel have dominated public political discussion in Tunisia and Morocco. In the aftermath of the rise of the Tunisian Ennahda Party and Moroccan Party of Justice and Development (PJD), political and electoral gains following post-Arab Spring parliamentary elections, and in direct response to Israeli calls for the emigration of the last remaining Jews, members of Ennahda and the PJD publicly assured Jewish communities that their rights and personal security would be guaranteed by the state. Later, it was rumored that both North African Islamic governments were set to nominate René Trabelsi and Serge Berdugo to be their next ministers of tourism, replicating past nominations of Jews to ministerial posts in the early decades of independence.

The social and political perception of Jews as "economic saviours" is culturally grounded in a traditional philo-Semitic North African admiration of Jews and their reputation as successful economic brokers. These perceptions align with the traditional belief that Jews possess "economic powers" that could revive a failing economy. Accordingly, Morocco, and to lesser degree Tunisia, have been widely engaged in a process of cultural conservation and redevelopment of Jewish sites, synagogues, and cemeteries, especially since the Oslo agreement. This conservation was largely initiated to encourage - though indirectly and unofficially-Israeli tourists of North African descent to visit Morocco and Tunisia. As a result, a new brand of Jewish heritage tourism began dominating the tourism industry of Tunisia and Morocco by the mid-1990s. Individual and group tourism packages catered to descendants of Jewish communities in Europe, North America, and Israel. As an option, Jewish cultural tours of Morocco and Tunisia can take tourists to rural and urban spaces once occupied by Jews whose descendants live today outside the region. In addition to these cultural and historical walks in the Jewish neighborhood (mellah or hära), visits to shrines, cemeteries, and Jewish religious festivals are a central part of this brand of Tunisian and Moroccan tourism.

Aomar Boum is Associate Professor of Anthropology at the University of California, Los Angeles. His research interests revolve around the Middle East as well as North, West, and Sub-Saharan Africa. His main research explores how generations of Moroccan Muslims remember, picture, and construct Moroccan Jews, Jewishness, and Judaism. His most recent publications include Memories of Absence: How Muslims Remember Jews in Morocco (Stanford University Press, 2013). He is currently finishing a coauthored manuscript on the monarchy, Jews, and Holocaust politics in Morocco; and a single authored book on the Baha'i Question in Morocco. 



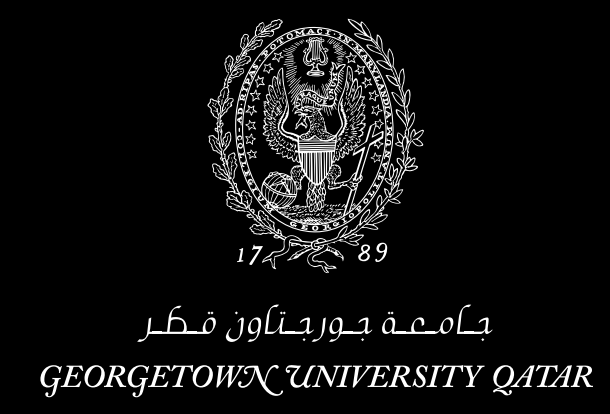

Center for International and Regional Studies

P. O. Box 23689, Qatar Foundation

Doha, State of Qatar

(C) 2018

http://cirs.georgetown.edu cirsresearch@georgetown.edu

Tel +97444578400

Fax +97444578401 